\title{
Komunikasi Bencana Palang Merah Indonesia melalui Siaga Bencana Berbasis Masyarakat dalam Menanggulangi COVID-19
}

\author{
Fajar Rizali Rakhman ${ }^{1}$, Edy Prihantoro ${ }^{2}$ \\ ${ }_{1,2}$ Magister Ilmu Komunikasi, Universitas Gunadarma \\ Jl. Margonda Raya No.100, Pondok Cina, Depok, 16424, Indonesia \\ Email: farizrakhman0507@gmail.com ${ }^{1 *}$; edipri@staff.gunadarma.ac.id ${ }^{2}$ \\ *Correponding author
}

\begin{abstract}
Bekasi City in 2020 has a population of 2,543,676 people spread over 12 sub-districts and 56 urban villages. There have been many cases of COVID-19 since last year so PMI Bekasi City involves the community through the community-based disaster preparedness program (SIBAT) in tackling COVID-19. The purpose of this research is to analyze the process of disaster communication and community involvement with PMI Bekasi City through the SIBAT program approach. This research uses Social Capital Theory, and the concept of Haddow and Haddow Disaster Communication. This study uses a qualitative approach with a single case study method, single analysis using interviews with six informants, namely the Head of Headquarters, Public Relations and Head of the Disaster Division of PMI Central and Bekasi City as well as two SIBAT volunteers, conducting observations, and documentation. The results showed that the disaster communication carried out by PMI Bekasi City with the SIBAT program played a very important role in tackling COVID-19 as a companion, mentor, counselor, and motivator in conveying disaster information by establishing mutual cooperation social capital. The application of social capital is very important to carry out as a synergy of cooperation during the COVID-19 pandemic. The substance of the research provides recommendations to all sectors in Indonesia to carry out responsible collaboration between various sectors to deal with COVID-19. Keywords: PMI Bekasi City; COVID-19; Community-Based Disaster Preparedness; Disaster Communication
\end{abstract}

\begin{abstract}
Abstrak
Kota Bekasi di tahun 2020 mempunyai jumlah penduduk mencapai 2.543.676 jiwa dengan tersebar di 12 kecamatan dan 56 Kelurahan. Terdapat banyak kasus COVID-19 sejak tahun lalu sehingga PMI Kota Bekasi melibatkan masyarakat melalui program siaga bencana berbasis masyarakat (SIBAT) dalam menanggulangi COVID-19. Tujuan penelitian ini untuk menganalisis proses komunikasi bencana dan keterlibatan masyarakat dengan PMI Kota Bekasi melalui pendekatan program SIBAT. Penelitian ini menggunakan Teori Modal Sosial, dan konsep Komunikasi Bencana Haddow dan Haddow. Penelitian ini menggunakan pendekatan kualitatif dengan metode studi kasus tunggal single analysis menggunakan wawancara kepada enam informan yaitu Kepala markas, Humas dan Kepala Divisi Kebencanaan PMI pusat dan Kota Bekasi serta dua relawan SIBAT, melakukan observasi, dan dokumentasi. Hasil penelitian menunjukkan komunikasi bencana yang dilakukan PMI Kota Bekasi dengan program SIBAT sangat berperan dalam menanggulangi COVID-19 sebagai pendamping, pembimbing, penyuluh, dan motivator dalam menyampaikan informasi kebencanaan dengan membentuk modal sosial gotong royong. Penerapan modal sosial sangat penting untuk dijalankan sebagai sinergitas kerja sama di masa pandemi COVID-19. Substansi penelitian memberikan rekomendasi kepada semua sektor yang ada di Indonesiauntukmelakukankerjasamayang bertanggungjawabantarberbagaisektoruntukmenanganiCOVID-19. Kata Kunci: PMI Kota Bekasi; COVID-19; Siaga Bencana Berbasis Masyarakat; Komunikasi Bencana
\end{abstract}

\section{Pendahuluan}

Indonesia mengalami peningkatan secara cepat setiap harinya pada kasus COVID-19. Tercatat dari awal kemunculannya di bulan Maret 2020 hingga bulan Juli 2021, kasus positif mengalami pertambahan sebesar 25.830 dengan akumulatifkeseluruhanmencapai2.228.938kasus (Fitra, 2021). Epidemiolog Griffith University
Australia Dicky Budiman menyatakan bahwa peningkatan ini diakibatkan minimnya kegiatan testing, tracing, dan isolasi atau karantina yang dilakukan oleh Pemerintah (Arnani, 2020).

Mengatasi permasalahan pandemi COVID-19 di Indonesia menjadi tanggung jawab semua sektor maupun komunitas yang ada dan dibutuhkan kerja sama antara instansi 


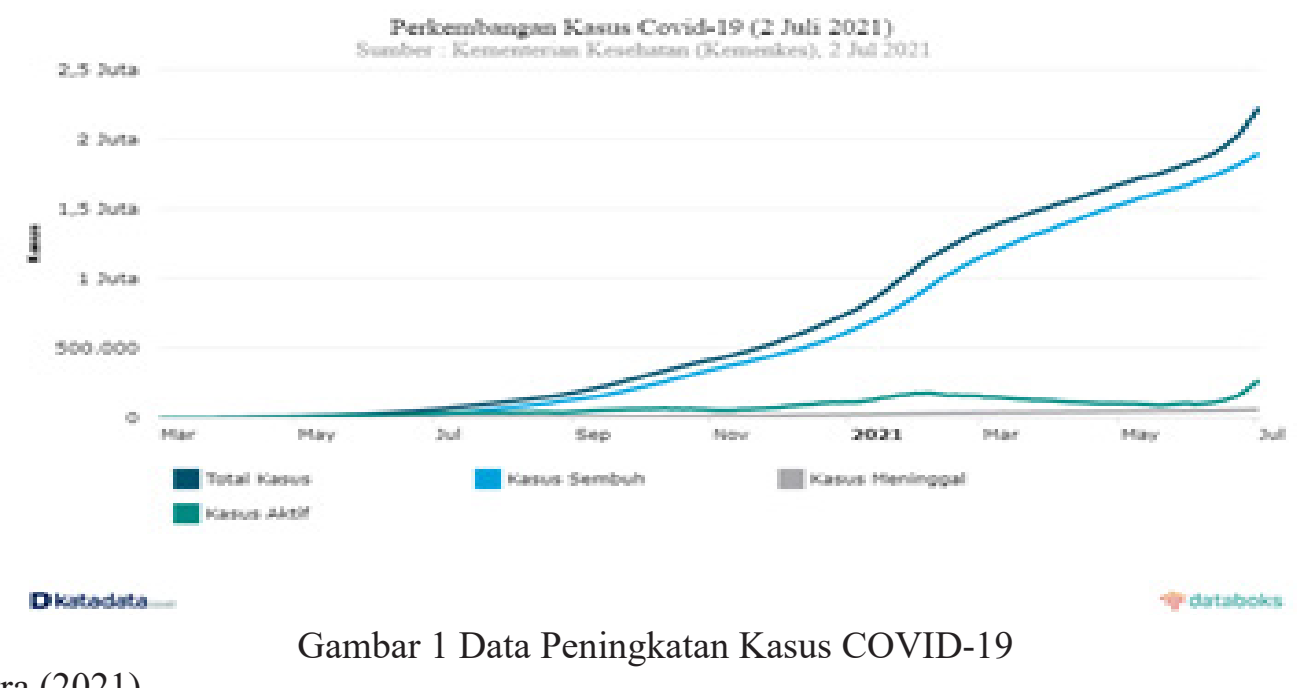

Sumber: Fitra (2021)

pemerintah, badan usaha, akademisi maupun masyarakat luas bukan hanya bergantung kepada pemerintah dan tim medis, sehingga Indonesia akan menang melawan COVID-19 (Burhanuddin et al., 2020:5; Widnyana, 2020:5). Kerja sama antar sektor maupun komunitas terbukti membantu mengatasi permasalahan pada wabah Ebola di Afrika Barat dan Republik Demokratik Kongo (Maher \& Murphet, 2020). Kerja sama dapat berjalan baik karena komunitas menjalankan manajemen yang baik dalam merancang, menerapkan, dan mengevaluasi dengan melibatkan peran pemimpin sehingga dapat melakukan penyebaran informasi (Schiavo, 2020). Kerja sama komunitas dalam kasus COVID-19 berperan dalam melakukan pencegahan dan pengendalian yang didesain berdasarkan perencanaan untuk membangun sebuah kepercayaan, komunikasi risiko, pengawasan dan penelusuran serta logistik administrasi (Gilmore et al., 2020) Indonesia telah melakukan pendekatan multisektor dalam upaya penanganan COVID-19. Salah satu sektor yang aktif terlibat adalah Palang Merah Indonesia (PMI). PMI berkontribusi dengan melibatkan masyarakat untuk meningkatkan kesadaran publik dalam penanganan COVID-19. Kesadaran publik dapat membangun serta menyebarluaskan pesan-pesan terkait COVID-19 melalui media, kolaborasi masyarakat, kebijakan mitigasi, dan dokumentasi (OCHA, 2020:41-42). Keterlibatan masyarakat dalam program PMI untuk menanggulangi COVID-19 dikemas dalam sebuah program bernama Siaga Bencana Berbasis Masyarakat (SIBAT). Program ini berasal dari masyarakat dan bekerja untuk masyarakat yang bersedia memberikan waktu, tenaga dan pikiran sebagai "the first responder" untuk melakukan pertolongan, penyelamatan diri, keluarga, maupun masyarakat. SIBAT diterapkan di lingkungan masyarakat sebagai upaya kesiapsiagaan bencana meliputi penggerak, pembimbing, penyuluh, dan motivator yang membantu pemerintah melalui desa atau kelurahan (PMI Pusat, 2007:40).

Peran masyarakat sangat dibutuhkan dalam menanggulangi COVID-19 di Indonesia. Peran masyarakat menjadi pondasi utama yang memiliki kekuatan dalam menggerakan kesadaran diri di lingkungannya untuk menjaga perilaku hidup sehat dan bersih, menahan dari keramaian dan melaksanakan kegiatan di rumah (Wahyu et al., 2020). Pondasi ini hadir karena adanya partisipasi masyarakat yang menjalankan aturan pemerintah dalam menanggulangi COVID-19 seperti, di rumah aja, 3M, menerapkan pola hidup sehat (Wahyu et al., 2020; Ertiana et al., 2020). 


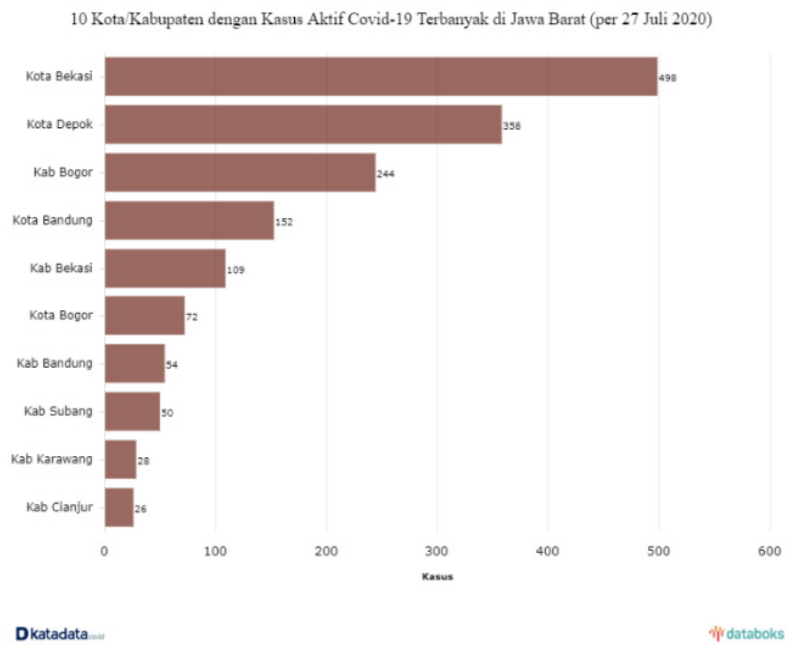

Gambar 2. Kasus COVID-19 Kota Bekasi di Jawa Barat

Sumber: Lidwina (2020)

Masyarakat sendiri merupakan faktor pendukung modal sosial dalam kebencanaan. Faktor ini didasarkan kepada modal sosial sebagai kekuatan masyarakat yang dapat menghadapi dan memulihkan diri dari bencana (Soeparno et al., 2020:xiii). Modal sosial yang membentuk kekuatan masyarakat ini dapat mempersatukan orang lain dengan melihat kesamaan permasalahan yang dialami dan mencari solusinya (Norzistya \& Handayani, 2020).

Pierre Bourdieu memperkenalkan Teori Modal Sosial pada akhir tahun 1970 dengan judul publikasi "Le Capital Social: Notes Provisoires" yangterbitdalam"ActesdelaRechercheenScience Social" (1980) menyatakan bahwa modal sosial memiliki sumber daya bersifat potensial untuk mewujudukan jaringan yang awet (durable) dan diinstitusionalisasikan dalam bentuk hubungan persahabatan (acquaintance) yang bersifat menguntungkan akan tetapi tidak secara alamiah (natural given) melainkan dikonstruksikan sebagai modal yang memiliki orientasi dengan hubungan kelompok (group relations) menjadi sumber terpercaya dalam meraih keuntungan (benefit) (Syafruddin, Suprianto, 2020:1).

Teori Modal Sosial berawal dari kebutuhan anggota masyarakat yang tidak dapat berjalan dengan sendiri untuk menghadapi masalah sehingga membutuhkan kerja sama dengan pihak lain untuk mengatasinya. Modal sosial menitikberatkan kepada kebersamaan, mobilitas, ide untuk menggerakan pencapaian suatu tujuan secara bersama (Hermanto Suaib, 2017:9). Anggota masyarakat yang dimaksud dalam Teori Modal Sosial dapat berupa suatu kelompok maupun organisasi (Tanzil et al., 2019)

Unsur penting dalam modal sosial adalah adanya hubungan yang harmonis di dalam komunitas (bonding), hubungan yang saling menguntungkan antarkelompok (bridging), dan hubungan yang memiliki makna antarkelompok berbeda (linking) (Wijaya et al., 2019).

Pemberdayaan SIBAT penting dibangun di daerah atau wilayah yang memiliki tingkat persebaran COVID-19 cukup tinggi. Salah satunya adalah Kota Bekasi dimana wilayah ini memiliki penyebaran tertinggi dengan memperoleh 498 kasus (Gambar 2). Angka tersebut membuat Kota Bekasi menjadi wilayah dengan kasus aktif terbanyak di Jawa Barat per 27 Juli 2020 (Lidwina, 2020). Pada awal tahun 2021, Kota Bekasi masih menjadi wilayah dengan tingkat penyebaran COVID-19 tinggi periode 18 Januari sampai dengan 24 Januari 2021 (Antara, 2021). Berdasarkan peta Pemerintah Provinsi Jawa Barat, kasus COVID-19 di Kota Bekasi Sempat mengalami penurunan pada 28 Februari 2021 ditandai dengan perubahan zona merah menjadi zona oranye di tingkat bawah atau skala Rukun Warga (RW) (Surjaya, 2021).

Penurunan kasus tersebut hanya bertahan selama 3 bulan dan kembali mengalami kenaikan kasus COVID-19 di Kota Bekasi pada Juni 2021 secara signifikan hingga 90\% sehingga membuat fasilitas Kesehatan menjadi kolaps (Warsono, 2021). Kenaikan ini diakibatkan adanya virus COVID-19 varian baru yang menyebar lebih cepat dibandingkan dengan varian sebelumnya (Wan, 2021). Berdasarkan data pada 28 Juni 2021 tercatat bahwa Kota Bekasi memiliki 52.210 kasus terkonfirmasi dengan rincian 48.532 sembuh, 3.005 kasus positif aktif dan 672 kasus meninggal dunia (Waluyo, 2021). 
Kenaikan kasus COVID-19 membuat pemerintah Kota Bekasi melibatkan PMI Kota Bekasi sebagai sektor yang membantu dalam menanggulangi COVID-19 dengan melibatkan masyarakat melalui program SIBAT. Penerapan program SIBAT pada tingkat kelurahan maupun desa sebagai lingkup terkecil di Kota Bekasi diharapkan dapat menekan penyebaran virus COVID-19.

Dalam penerapan SIBAT, PMI Kota Bekasi memerlukan komunikasi bencana yang dibutuhkan sebagai persiapan keperluan menghadapi bencana (Sukmono et al., 2019:84) dalam proses penyampaian pesan atau informasi kebencanaan secara cepat, akurat dan mudah dijangkau secara menyeluruh (Lestari, 2019:11) dan bagaimana proses penyampaian yang dilakukan antarakelompok, lembaga bencana maupun kemanusiaan yang dikoordinasikan secara optimal (Nugroho \& Sulistyorini, 2018:2).

Komunikasi bencana juga dikenal sebagai bagian dari manajemen bencana yang memiliki peran dan fungsi sebagai penerimaan pesan pengurangan risiko kebencanaan yang diproduksi untuk disebarkan pesan dan informasi didalamnya yang meliputi prabencana, saat bencana, dan pascabencana (Lestari et al., 2012). Risiko bencana yang dimaksud adalah ancaman bencana, kebutuhan korban, maupun berbagai evaluasi risiko bencana (Lestari et al., 2020)

Pembentukan informasi dan pesan kebencanaan dikirimkan kepada aktor kebencanaan seperti BMKG, BPBD dan pemerintah daerah (Kholil et al., 2019). Informasi dan pesan kebencanaan dalam komunikasi bencana bersifat aktual dan akurat yang dapat menjadi tombak utama kebencanaan untuk dapat mengenali respon, mengidentifikasikan suatu risiko, dan pemulihan kebencanaan pada saat bencana dinyatakan selesai (Abidin, 2021). Komunikasi bencana juga dapat menjadi korektor dari rumor bencana yang beredar mengenai berbagai informasi yang dapat mempengaruhi pemulihan terhadap suatu bencana (Spialek \& Houston, 2019).
Terdapat lima landasan utama komunikasi bencana yang dikemukakan Haddow dan Haddow dalam Nugroho \& Sulistyorini (2018) yang membangun sebuah proses komunikasi bencana melalui: (1) Customer Focus sebagai informasi yang dibutuhkan; (2) Leadership Commitment komitmen dalam tanggap darurat bencana sebagai komunikasi yang efektif; (3) Situational Awareness cara data tersebut didapatkan dengan menekankan pada unsur transparansi dan akuntabilitas; (4) Media parnership sebagai penyebaran informasi kepada publik; dan (5) Pendekatan soft power dan hard power meliputi kegiatan yang dilakukan secara halus yakni berupa mitigasi bencana dengan pemberian informasi dan secara keras yakni aksi nyata seperti pembangunan fasilitas.

Beberapa penelitian terdahulu terkait komunikasi bencana yang menjadi landasan dalam penelitian ini dilakukan oleh $\mathrm{K}$ dan Umam (2019) yang menyatakan bahwa komunikasi bencana memiliki suatu sistem kesatuan terpadu yang menghubungkan antara komunikasi dengan bencana mengenai penyamaan, penyampaian, pengelolaan dan mengontrol persepsi serta arus informasi dalam suatu kebencanaan yang membutuhkan suatu respon untuk memulihkan kebencanaan dengan melibatkan pemangku kepentingan dalam hal ini stakeholder meliputi, pemerintah, sektor swasta, LSM dan organisasi sejenis. Penelitian terdahulu yang dilakukan oleh Noor et al. (2020) menyatakan bahwa komunikasi bencana di masa COVID-19 sangat diperlukan dan dibutuhkan sebagai media dalam proses berlangsungnya komunikasi antara penderita COVID-19 dengan keluarga, staf media dan komunitas. Penelitian terdahulu selanjutnya dilakukan oleh Murliana et al. (2020) menyatakan bahwa komunikasi dapat digunakan dalam penyampaian pesan kebencanaan melalui pendekatan budaya kesenian dengan media pertunjukkan wayang kulit yang dimaksudkan untuk menumbuhkan peningkatan pemahaman masyarakat terkait penanggulangan bencana di Kabupaten Puworejo. 
Berdasarkan latar belakang di atas, penelitian ini mengenai bagaimana PMI Kota Bekasi menggunakan komunikasi bencana melalui pendekatan SIBAT untuk menekan dan mengurangi kasus positif COVID-19 di Kota Bekasi. Penelitian ini mempunyai tujuan untuk menganalisis proses komunikasi bencana dan keterlibatan masyarakat dengan PMI Kota Bekasi melalui pendekatan program SIBAT dalam menanggulangi COVID-19 demi memutus mata rantai penyebaran di Kota Bekasi.

\section{Metode Penelitian}

Kualitatif dipilih dalam penelitian ini yang dijadikan sebagai metode penelitian dengan pendekatan studi kasus tunggal single analysis untuk menjelaskan mengenai aspek individu, kelompok, organisasi dalam peristiwa tertentu secara mendalam utuh, holistik, intensif dan naturalistik dengan menyoroti perilaku kelompok individu pada satu masalah penting yakni PMI Kota Bekasi dalam menjalankan komunikasi bencana berbasis masyarakat (Ismail Nurdin, 2019; Kadji, 2016; Suwendra, 2018). Jenis penelitian ini adalah deskriptif yang nantinya menggambarkan realitas yang ada dan terjadi tanpa mengkaitkannya dengan variabel (Kriyantono, 2016:69).

Paradigma penelitian ini adalah konstruktivisme, dimana realitas sosial yang ada tidak dapat digeneralisasikan karena masingmasing memiliki pemahaman beragam, peneliti mencoba mengetahui atau menterjemahkan realitas pada makna yang dibawa kepada narasumber (Helmi, 2020) dan hasil konsekuensi aktivitas yang dibentuk tidak pernah dipertanggungjawabkan kebenarannya karena permasalahan selalu berubah (Ardianto, 2010:70, Gubah, 1990:26, dalam Samatan, 2017:133).

Penelitian ini menggunakan wawancara langsung indepth interview dan observasi terus terang kepada tiga informan kunci yakni Imam Tri Subekti sebagai Kepala Markas PMI Kota Bekasi, Agung Cahyono sebagai Humas PMI
Kota Bekasi, Muhammad Yamin sebagai Kepala Divisi Kebencanaan, dan tiga informan non kunci yang digunakan sebagai triangulasi data sumber yakni Fajar Andrianto Wibowo, Reja sebagai relawan SIBAT dan Arifin Muhammad Hadi sebagai Kepala Divisi Kebencanaan PMI Pusat.

Selain wawancara, data juga didapatkan dari sumber lain seperti literatur buku, jurnal, artikel, serta situs internet. Data yang telah didapatkan kemudian dianalisis dengan cara disederhanakan dari temuan lapangan agar menjadi ringkas (reduksi data), disajikan ke dalam paragraf naratif agar mudah dipahami, dan menarik kesimpulan (verifikasi) yang menjadi penemuan atau hasil penelitian terkait komunikasi bencana Palang Merah Indonesia Kota Bekasi dalam menanggulangi COVID-19 dengan pendekatan siaga bencana berbasis masyarakat (Wijaya, 2018:56-59).

\section{Hasil Penelitian Dan Pembahasan}

Komunikasi Bencana PMI Kota Bekasi dalam Menanggulangi COVID-19 melalui Pendekatan Siaga Bencana Berbasis masyarakat

Pada penelitian ini peneliti ingin melihat, mengkaji, dan menganalisis bagaimana PMI Kota Bekasi dalam menjalankan komunikasi bencana melalui pendekatan SIBAT pada masa pandemi COVID-19. Peneliti menggunakan konsep komunikasi bencana yang diperkenalkan oleh Haddow dan Haddow yang menjadi landasan utama berjalannya komunikasi bencana.

1) Costumer Focus, yang merupakan fase awal dalam komunikasi bencana dengan melihat berbagaimacamkebutuhanterkaitpenangulangan bencana COVID-19 di wilayah tempat tinggal masyarakat. PMI Kota Bekasi melakukan perizinan dimulai dari Satgas COVID-19 dengan dinas terkait di Kota Bekasi, lalu ke level bawah seperti pejabat RT, RW, kelurahan, yang juga melibatkan tokoh masyarakat kemudian langsung kepada masyarakat di wilayah tempat tinggal. Costumer Focus yang dilakukan oleh PMI Kota Bekasi dalam menanggulangi 
COVID-19 melalui pendekatan SIBAT ini menggunakan teknik persuasif dimana PMI Kota Bekasi mengajak melalui sosialisasi edukasi dan pembekalan teknis dengan melakukan seminar kepada masyarakat sekitar di lingkungan RT. Materi yang diberikan berupa prosedur isolasi mandiri yang baik, mendemonstrasikan 3M, praktik penyemprotan disinfektan. Dalam sosialisasi tersebut, dialog yang dibangun bersifat dua arah dengan melakukan tanya-jawab antara masyarakat dengan PMI Kota Bekasi terkait kegiatan yang dilaksankan di lingkungan tersebut dan kebutuhan yang diinginkan. Dari hasil dialog tersebut, masyarakat membutuhkan aksi nyata berupa kegiatan-kegiatan yang dapat mengurangi penyebaran kasus COVID-19.

2) Leadership Commitment, fase dimana adanya pembentukan komitmen. Komunikasi bencana membutuhkan komitmen untuk dapat menanggulangi bencana. Faktor pemimpin berperan sangat penting dalam komunikasi bencana sebagai leadership commitment yakni proses komunikasi bencana yang difungsikan menjadi setting atau pengatur jalannya sebuah organisasi. Pemimpin bertugas sebagai pengambil keputusan untuk melakukan kegiatan penanggulangan bencana COVID-19.

PMI Kota Bekasi mengikuti kebijakan dan arahan yang berasal dari pimpinan PMI Pusat dan Pemerintah. Arahan dan kebijakan yang diberikan oleh pemimpin tertuang dalam beberapa peraturan berikut: 1) UU Kepalangmerahan No.1 tahun 2018 pada bab VI Peran Masyarakat Pasal 32, 2) AD/ART PMI Tahun 2019-2024 pada pasal 14 Pembinaan Relawan dan pasal 15 Pendidikan Dan Pelatihan Kepalangmerahan, 3) Mandat PMI berdasarkan Keputusan Presiden No.25 tahun 1950 dan No.246 Tahun 1963, 4) Rencana Strategis PMI Tahun 2019-2024, 5) Resolusi PBB Terkait penanggulangan bencana yakni pengesahan Sendai Declaration and The Sendai Framework for Disaster Risk Reduction 2015-2030, 6) Peraturan Menteri Sosial RI
Nomor 128 tahun 2011 tentang Kampung Siaga Bencana pada pasal 3, 7) Peraturan kepala BNPB no.1 Tahun 2012 tentang Pedoman Umum Desa atau Kelurahan Tangguh Bencana pada bab IV kegiatan dalam mengembangkan desa atau kelurahan Tangguh bencana poin pembentukan forum PRB desa atau kelurahan. Peraturanperaturan tersebut diturunkan kepada Ketua PMI Kota Bekasi dilaksanakan pada Kepala Markas PMI Kota Bekasi sebagai teknis pelaksana yang nantinya disebarluaskan kepada anggota lainnya. Hal tersebut merupakan bagian dari leadership yang dilakukan oleh PMI Kota Bekasi. Komitmen kuat berasal dari PMI Pusat hingga daerah yang ingin memerangi COVID-19 hingga tuntas dan akhirnya status pandemi dicabut oleh WHO. "Kita ikut aturan dari PMI Pusat. Komitmen kita akan melakukan pencegahan dan penanganan COVID ini sampai selesai sampai pandemi ini dicabut oleh WHO (Imam Tri Subekti, Kepala Markas PMI Kota Bekasi, 16 Maret 2021)".

3) Situational Awareness, fase ini merupakan fase untuk mengetahui cara mendapatkan dan menyebarkan data secara transparan dan akuntabel. PMI Kota Bekasi melakukan pengumpulan data melalui observasi secara langsung dan data-data pendukung dari sektor lainnya. Data tersebut didapatkan oleh PMI Kota Bekasi dari Satgas COVID-19 yang berada di Stadion Candra Baga Kota Bekasi (GOR), dan dinas terkait yang meliputi, Dinas Kesehatan, Dinas Sosial, dan BPBD. Data menjadi bagian penting dalam proses komunikasi bencana. Tanpa adanya data, informasi yang disebarkan tidak kredibel yang berdampak pada rendahnya pemahaman masyarakat. Data berfungsi sebagai pembentukan perencanaan yang juga merupakan analisa tepat dalam proses keselamatan seperti, kelompok rentan bencana, prasarana umum dan dapat digunakan sebagai penentu kebijakan untuk mengukur keberhasilan dari kebencanaan (Nugroho \& Sulistyorini, 2018). 


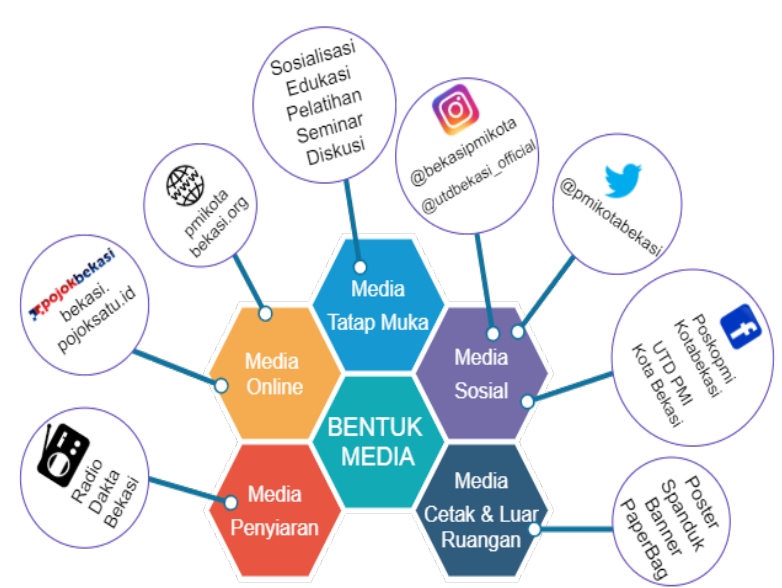

Gambar 3 Bentuk Media Komunikasi Bencana PMI Kota Bekasi Dalam Menanggulangi COVID-19 Sumber : Olahan Peneliti (2021)

Pada saat data didapatkan, PMI Kota Bekasi melakukan transparansi data melalui mediamedia yang dimilikinya untuk disebarluaskan dan dipertanggungjawabkan kepada publik (akuntabilitas). PMI Kota Bekasi terbuka mengenai data sehingga publik mengetahui fakta terkait pengendalian COVID-19 di Kota Bekasi. Keterbukaan ini merupakan salah satu sistem organisasi kebencanaan yang dimiliki oleh PMI Kota Bekasi untuk menginformasikan kepada semua elemen masyarakat. "Yadiperlukan karenakitajuga menggunakan anggaran jadi kita harus transparan akuntabilitasnya juga disampaikan apalagi kita melibatkan masyarakat lewat laporan informasi yang sudah dilakukan. Mungkin nanti jika ada penggunaan beberapa saranasarana yang menggunakan anggaran akan disampaikan kepada masyarakat (Imam Tri Subekti, Kepala Markas PMI Kota Bekasi, 16 Maret 2021)". 4) Media Partnership, adalah saluran komunikasi yang digunakan oleh PMI Kota Bekasi dalam mengkomunikasikan bencana melalui pendekatan SIBAT. Media ini digunakan PMI Kota Bekasi untuk menyebarkan pesan informasi kepada masyarakat melalui berbagai macam platform yang tersedia dalam Gambar 3.
Pesan informasi tersebut bersifat persuasif atau ajakan yang mengarah kepada pencegahan COVID-19 seperti halnya di rumah aja, jaga jarak, dilarang berkumpul, pemberian contoh cuci tangan yang baik, informasi terkait donor darah setelah terkena COVID-19.

PMI Kota Bekasi memiliki media sosial untuk menyebarkan informasi kebencanaan COVID-19 dan pencegahanya menggunakan infografis. Pemanfaatan media sosial sangat penting digunakan oleh Palang Merah Indonesia karena media sosial memiliki accessibility yang dapat menjangkau publik secara mudah, instan, dapat bertahan dalam waktu yang lama, serta akses yang tidak terbatas (Kanwar, 2012). Pemanfaatan media sosial juga dapat melihat tujuan, target, dan hasil yang diharapkan (Saputri et al., 2021). Selain itu, media sosial banyak digunakan oleh masyarakat sebagai sumber informasi karena kecepatan dan jangkauannya yang luas. Penyebaran informasi dan sosialisasi tidak memerlukan sumber daya yang banyak sehingga dapat menghemat biaya pengeluaran (Hidayat et al., 2020). Jangkauan media sosial yang dimiliki PMI menempati posisi kedua terluas di Asia Pasifik. Pemanfaatan media sosial gencar diberlakukan sebagai media komunikasi bencana di masa pandemi COVID-19. "Penggunaan sosial media itu menjadi sangat penting bagi kami di masa pandemi COVID-19. Sehingga kami mendorong publik memanfaatkan media sosial karena sosial media PMI terbesar kedua di Asia Pasifik, lebih tinggi dibandingkan dengan yang lainnya (Arifin Muhammad Hadi, Divisi Penanggulangan Bencana PMI Pusat, 18 Juni 2021)". Media sosial yang digunakannya antara lain adalah, Facebook, Twitter, Instagram, Whatsapp grup yang menghubungkan relawan PMI Kota Bekasi dengan relawan SIBAT. Media sosial sendiri digunakan PMI Kota Bekasi karena feedback yang didapatkan lebih besar 


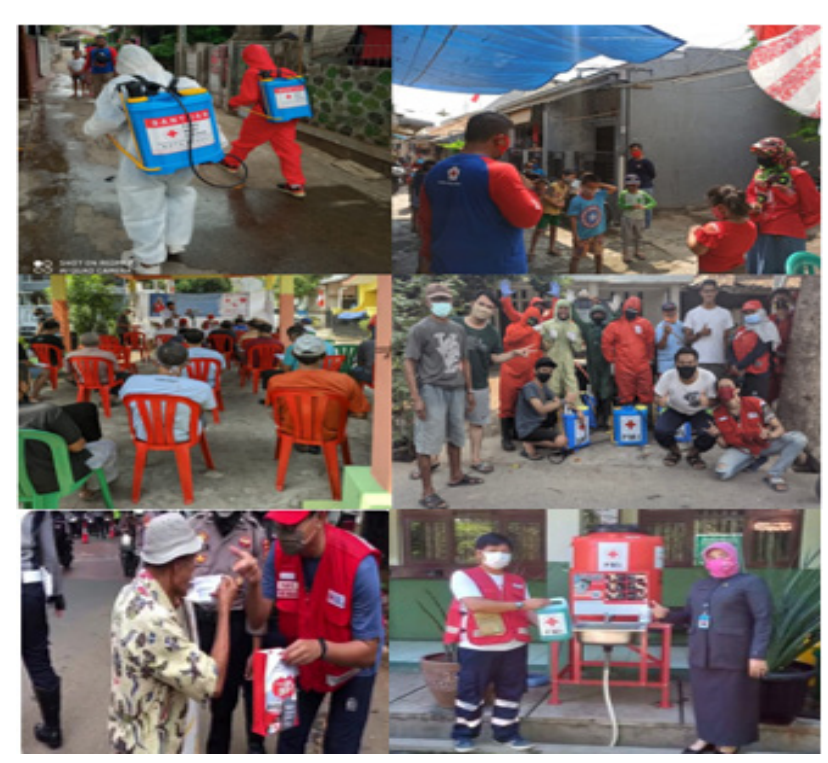

Gambar 4 Kegiatan PMI Kota Bekasi bersama dengan Relawan SIBAT dalam Menanggulangi COVID-19

Sumber: PMI Kota Bekasi \& Relawan Sibat PMI Kota Bekasi (2021)

dibandingkan dengan media lainnya. Hal ini diperkuat dari hasil penelitian survei PMI dan IFRC yang dilakukan dengan penilaian cepat (rapid assessment) untuk mengetahui cara berkomunikasi dengan masyarakat. Data diambil dari responden yang berasal dari 19 provinsi di Indonesia. Hasil survei menunjukkan bahwa media sosial mendapatkan nilai tertinggi yakni 45.2\% dibandingkan media lain seperti, Hotline 28,44\%, SMS 13,29\%, Tatap Muka 10,72\%, Radio 1,86\%, Email 0,47\% dalam hal feedback atau umpan balik di masa COVID-19. Umpan balik dapat disampaikan melalui kolom komentar, pesan langsung, tagar atau menggunakan ChatBot (balasan pesan otomatis) (PMI \& IFRC, 2020). Hasil penelitian tersebut diperkuat oleh penelitian dari Rohmah (2020) yang menyatakan bahwa media sosial merupakan platform sebagai saluran penyampaian dan penyebaran informasi seputar COVID-19 yang dapat memuaskan penggunanya dengan perolehan nilai mencapai 92\%. Selain media sosial, PMI Kota Bekasi juga melakukan komunikasi tatap muka untuk mengkomunikasikan bencana kepada masyarakat dalam menanggulangi COVID-19 di Kota Bekasi. Komunikasi tatap muka yang dilaksanakan PMI Kota Bekasi yakni sosialisasi, edukasi, seminar dan pelatihan yang berlangsung secara dua arah ditandai dengan adanya diskusi atau dialog pendapat.

PMI Kota Bekasi juga melakukan kerja sama atau partnership dengan berbagai media eksternal baik online, maupun massa seperti Radio Dakta, dan Pojoksatu Bekasi juga stakeholder untuk mendukung dan mempermudah jalannya penanggulangan bencana COVID-19 di Kota Bekasi. Selain masyarakat, PMI Kota Bekasi juga berkerja sama dengan pemerintah sebagai mitra partnership-nya. Kerjasama dilakukan karena PMI tidak dapat berjalan sendiri sebagai organisasi kemanusiaan sehingga membutuhkan dukungan dari sektor lainnya. Dalam menjalankan komunikasi bencana dibutuhkan kerja sama dengan aktor-aktor lainnya.

5) Pendekatan Soft power dan Hard power, fase ini terdiri dari fase halus dalam bentuk mitigasi bencana dan fase kasar yakni aksi nyata dalam pembangunan dan pembagian fasilitas. Pada soft power, costumer focus merupakan bentuk dari komunikasi bencana secara mitigasi sebagai langkah kesiapan menghadapi bencana untuk mengurangi kemungkinan korban jiwa, atau kerugian harta benda (Wekke, 2021:11). Kegiatan ini merupakan bagian dari knowledge kesehatan yang membekali masyarakat sehingga dapat mengurangi penyebaran kasus COVID-19.

Bukan hanya pemberian informasi saja, namun PMI Kota Bekasi juga melakukan pembangunan dan membagikan fasilitas sarana prasarana alat untuk menanggulangi COVID-19 di Kota Bekasi yakni pembangunan tempat cuci tangan yang ada di lingkungan sekolah, tempat ibadah, di pasar dan di tempat umum lainnya, membagikan alat PHBS (Perilaku Hidup Bersih Sehat) seperti masker, hand sanitizer. Kegiatan tersebut merupakan bentuk komitmen nyata PMI Kota Bekasi dalam menanggulangi COVID-19. 
Tabel 1 Kegiatan Komunikasi Bencana PMI Kota Bekasi dengan Melibatkan Masyarakat melalui SIBAT

\begin{tabular}{ll}
\hline No & \multicolumn{1}{c}{ Kegiatan } \\
\hline 1. & Menyebarkan pesan berantai (broadcast) pesan-pesan terkait COVID-19 dari PMI ke dalam \\
Whatsapp Grup masyarakat di tingkat RT/RW \\
2. Bekerja sama dengan tokoh masyarakat untuk memastikan kegiatan penanggulangan bencana \\
COVID-19 di Kota Bekasi berlangsung dengan baik \\
3. Menggunakan saluran media sosial untuk menyebarkan pesan-pesan kebencanaan pencegahan \\
4. Meputar COVID-19 \\
5. Menasang dan membagikan poster-poster COVID-19 di area yang sering didatangi atau dikunjungi \\
6. Mencatat saran, keluhan dan pertanyaan dari masyarakat terkait kegiatan penanggulangan bencana \\
COVID-19 berbasis masyarakat melalui relawan SIBAT dan relawan PMI menggunakan \\
kobocollect ataupun laporan manual
\end{tabular}

Sumber: Olahan Peneliti (2021)

"Kita melakukan edukasi, sosialisasi tentang isolasi mandiri, pencegahan COVID dan paling nyata itu penyemprotan di 800 titik di wilayahKotaBekasi.Kegiatankamidirasakan oleh masyarakat (Imam Tri Subekti, Kepala Marlas PMI Kota Bekasi, 16 Maret 2021)". Hal ini juga merupakan bagian dari upaya melindungi masyarakat berdasarkan ruang lingkup kesehatan masyarakat. Terdapat empat usaha yang dilakukan untuk melindungi masyarakat dalam ranah kesehatan di antaranya adalah promotif (promosi mengenai Kesehatan yang bertujuan untuk peningkatan kesehatan), preventif (kegiatan yang bersifat pencegahan dari penyakit), kuratif (pengobatan) dan rehabilitatif (pemulihan kesehatan) (Effendi Sianturi, Maida Pardosi, 2019).

Berdasarkan hasil temuan yang ditemukan dalam penelitian ini, upaya kesehatan yang dilakukan oleh PMI Kota Bekasi dalam menanggulangi kasus COVID-19 berbasis masyarakat hanya mencapai pada level promotif dan preventif. Upaya yang dilakukan berupa sosialisasi informasi kepada relawan SIBAT untuk membangun kesadaran dan meningkatkan mengenai pentingnya perilaku hidup bersih dan sehat dalam menghadapi bahaya COVID-19, melakukan dialog jajak pendapat secara dua arah untuk memenuhi kebutuhan masyarakat dengan menerima dan menjawab saran, pertanyaan, atau keluhan masyarakat yang dikoordinasikan bersama dengan tim PMI, menciptakan masyarakat yang tenang dan paham mengenai prosedur menghadapi COVID-19 di lingkungan terdekatnya.

Kegiatan komunikasi bencana PMI Kota Bekasi dalam menanggulangi COVID-19 dengan melibatkan masyarakat telah peneliti uraikan dan deskripsikan kedalam Tabel 1.

\section{PMI Kota Bekasi dalam Melibatkan Masyarakat melalui Pendekatan Siaga Bencana Berbasis Masyarakat dalam Menanggulangi COVID-19}

PMI selalu hadir membantu menanggulangi bencana. Kehadiran PMI menunjukkan peran penting PMI sebagai aktor bencana yang menjadi garda terdepan dalam menolong sesama sesuai dengan tugas pokok dan fungsi tujuh prinsip dasar gerakan kepalangmerahan yang dimilikinya. Gerak cepat yang dilakukan oleh PMI memudahkan penanggulangan bencana di Indonesia. Kecepatan PMI dalam melakukan penanggulangan bencana sudah menjadi pedoman atau protokol yang wajib dilaksanakan oleh seluruh relawan PMI di 
Tabel 2 Data SIBAT PMI Kota Bekasi

\begin{tabular}{cccc}
\hline No & Kelurahan & Kecamatan & Penanggung Jawab \\
\hline 1. & Aren Jaya & Bekasi Timur & Lenih Noviana \\
2. & Pekayon Jaya & Bekasi Selatan & Neneng Sintawati \\
3. & Kota Baru & Bekasi Barat & Zumrotullaila \\
4. & Perwira & Bekasi Utara & Ukati \\
5. & Duren Jaya & Bekasi Timur & Isman \\
6. & Pengasinan & Rawalumbu & Juanita Handayani \\
7. & Bojong Rawalumbu & Rawalumbu & Elvina. E \\
8. & Mustikasari & Mustika Jaya & Titik Karomah \\
9. & Kayuringin & Bekasi Selatan & Fajar Andrianto \\
10. & Harapan Mulya & Medan Satria & A.Sholeh \\
\hline Sula
\end{tabular}

Sumber: PMI Kota Bekasi, 25 Maret 2021

Indonesia. Dalam kurun waktu enam jam, relawan PMI harus sampai di tempat bencana di mana pun di Indonesia (Katriana, 2020).

Bulan Maret 2020 yang merupakan kemunculan pertama kali COVID-19 di Indonesia membuat PMI bergerak berdasarkan mandat yang telah didapatkan dari pemerintah untuk bergerak membantu menanggulangi COVID-19 di Indonesia. "Terkait penanggulangan COVID-19, PMI dimandatkan untuk membantu pemerintah dalam menanggulangi bencana COVID-19 (Muhammad Yamin, Divisi Penanggulangan Bencana PMI Kota Bekasi, 16 Maret 2021)". Dari mandat ini PMI segera mengerahkan personil yang dimilikinya di setiap wilayah di Indonesia dengan melibatkan peran serta masyarakat melalui program yang digagasnya yakni Siaga Bencana Berbasis Masyarakat (SIBAT). "Sejak awal COVID-19 di Bulan Maret kita sudah memobilisasi seluruh anggota SIBAT ini untuk bergerak di wilayah masing-masing. SIBAT menunjukkan peran yang luar biasa (Arifin Muhammad Hadi, Divisi Penanggulangan Bencana PMI Pusat, 18 Juni 2021)".

Pelaksanaan program penanggulangan bencana melalui SIBAT dalam menanggulangi COVID-19 dijalankan di tingkat cabang yang mencakup kota atau kabupaten dengan memberdayakan PMI Ranting di tingkat kecamatan. PMI Kota Bekasi yang berada di tingkat cabang dalam menanggulangi
COVID-19 telah melibatkan masyarakat melalui relawan SIBAT yang tersebar di 10 kelurahan dan 6 kecamatan dari keseluruhan yang dimiliki oleh Kota Bekasi sejumlah 56 kelurahan dan 12 kecamatan. Hal ini merupakan langkah baik yang dilakukan PMI Kota Bekasi dalam melibatkan masyarakat melalui relawan SIBAT.

Pemberdayaan masyarakat dalam penanggulangan bencana sudah lama dilakukan sebelum organisasi palang merah berdiri. Hal ini karena basis kerelawanan berasal dari masyarakat. Hanya saja saat awal berdirinya PMI pada 17 September 1945, relawan masyarakat belum diresmikan sebagai Siaga Bencana Berbasis Masyarakat (SIBAT) dan menggunakan nama lain seperti SATGANA (Satuan Penanganan Bencana). SIBAT diresmikan sejak 2007 setelah tsunami besar melanda Aceh. SIBAT dibentuk untuk menjadi penolong bagi masyarakat dari masyarakat ketika terjadi bencana sehingga tidak bergantung kepada pihak manapun. "Dulunya mungkin ada, karena basis kerelawanan kita itu di masyarakat tapi namanya belum resmi. Tapi sekarang sudah diresmikan sejak tahun 2007 setelah tsunami Aceh melanda yang membawa dampak luar biasa, masyarakat tidak boleh tergantung dari bantuan pihak ketiga untuk bisa menyelematkan diri sendiri dan juga anggota keluarganya dari dampak bencana (Arifin Muhammad Hadi, Divisi Penanggulangan Bencana PMI Pusat, 18 Juni 2021)". PMI Kota Bekasi melibatkan masyarakat melalui program SIBAT bertujuan untuk memudahkan kinerja PMI Kota Bekasi dalam mendapatkan informasi yang ada di lapangan mengenai kebutuhan apa yang diperlukan, serta kondisi karakteristik wilayah bencana, sehingga mempercepat gerak PMI Kota Bekasi dalam menanggulangi bencana COVID-19. Tanpa bantuan masyarakat, PMI Kota Bekasi tidak dapat berjalan dengan baik karena sumber daya yang dimiliki oleh PMI Kota Bekasi berasal dari masyarakat dan untuk masyarakat dalam melakukan kegiatannya. 
"Tidak bisa, relawan PMI sendiri berasal dari masyarakat. PMI melakukan open recruitment anggota dan banyak warga Kota Bekasi yang bersedia mendaftar menjadi relawan (Agung Cahyono, Humas PMI Kota Bekasi, 15 Maret 2021)". PMI merupakan organisasi kemasyarakatan dengan, berintegritas dan bergerak bersama masyarakat yang fokus memberikan pelayanan kepada masyarakat sesuai prinsip yang dimilikinya mengacu pada Gerakan kepalangmerahaan dan bulan sabit merah, kerja sama dilakukan bersama stakeholder yang dapat meningkatkan integritas kemandirian organisasi berpihak kepada masyarakat yang memerlukan bantuan sesuai dengan Visi-Misi yang dijalankan (PMI, 2021).

Kinerja PMI Kota Bekasi terganggu dan terhambat apabila tidak melibatkan relawan SIBAT karena jumlah relawan PMI Kota Bekasi yang terlatih (KSR) sangat terbatas yaitu sekitar 205 anggota. Angka tersebut tidak cukup untuk melakukan pengendalian COVID-19 di Kota Bekasi yang penduduknya mencapai 2.543.676,00 (Badan Pusat Statistik Kota Bekasi, 2020). Peran relawan SIBAT menjadikan fundamental utama sebagai support system PMI Kota Bekasi dalam menangani kasus pandemi COVID-19. Masyarakat merasakan dampak positif keberadaan PMI Kota Bekasi. Tanpa adanya peran PMI Kota Bekasi sebagai fasilitator, masyarakat akan kesulitan menangani COVID-19 secara baik, dan sesuai dengan standarisasi prosedural yang telah ditentukan dan ditetapkan oleh WHO.

"Masyarakat juga akan kesulitan bila tidak ada bantuan dari PMI, seperti bimbingan cara spraying, bantuan alat-alat kebersihan dan spraying dan lain-lain (Reja, Relawan SIBAT PMI Kota Bekasi, 22 Maret 2021)”.

Dalam menangani COVID-19, masyarakat dan PMI saling membutuhkan dan saling melengkapi. PMI Kota Bekasi membutuhkan masyarakat sebagai pendukung jalannya program SIBAT yang memudahkan PMI Kota Bekasi dalam menanggulangi COVID-19. Sebaliknya, masyarakat juga membutuhkan informasi yang diperoleh dari PMI Kota Bekasi sebagai bekal dalam penanganan COVID-19.
"Dalam hal ini, kita saling membutuhkan. Kita butuh ilmunya kemudian PMI butuh pengaplikasiannya di masyarakat (Fajar Andrianto Wibowo, Relawan SIBAT, 23 Maret 2021)." Berdasarkan data yang diperoleh peneliti di lapangan, Teori modal sosial cocok diterapkan dalamfenomenayangdiangkatpadapermasalahan penelitian ini. Kecocokan ini berdasarkan pernyataan teori modal sosial yang menyatakan bahwa kebutuhan anggota masyarakat baik kelompok maupun organisasi tidak berjalan dengan sendiri dan mengutamakan kerja sama dengan pihak lain untuk mengatasinya. Dalam hal ini, elaborasi antara hasil penelitian dengan teori yang dipergunakan didapati bahwa sektor organisasi yakni, PMI Kota Bekasi bersinergitas dan bekerja sama dengan kelompok masyarakat menggunakan ide yang digagas berupa program kerja yang dimilikinya bernama Siaga Bencana Berbasis Masyarakat (SIBAT) melalui relawan masyarakat yang ada dilingkup terkecil yakni RT, RW, dan Desa yang telah dimobilisasi untuk mencapai kepentingan yang sama didasarkan atas keinginan untuk menyelesaikan sebuah permasalahan yang dihadapi yaitu COVID-19.

Pierre Bourdieu melihat modal sosial yang dijalin antara anggota masyarakatyaknikelompok maupun organisasi sebagai hubungan yang awet berdasarkan kepentingan yang sama dalam suatu anggota masyarakat untuk mencapai suatu tujuan bersama dalam keuntungan yang diinginkan.

Hubungan yang dijalin PMI dengan masyarakat sudah berlangsung cukup lama, jauh sebelum PMI diresmikan 76 Tahun lalu. Hubungan yang sudah terjalin lama antara PMI dan masyarakat mampu menciptakan hubungan awet (durable) dalam jangka waktu yang panjang dengan suatu kelompok layaknya seorang sahabat yang sudah saling mengenal. Hubungan ini tentunya tidak terbentuk secara alamiah melainkan hasil konstruksi yang dilakukan untuk menghasilkan suatu hubungan dengan maksud tertentu. Konstruksi yang dibangun oleh PMI Kota Bekasi dimaksudkan untuk 
membantu kinerjanya dalam penanggulangan COVID-19. Konstruksi ini adalah hasil dari sosialisasi, edukasi, dan pelatihan masyarakat yang diperkenalkan PMI sehingga menghasilkan orientasi kelompok masyarakat bahwa PMI merupakan modal sosial terpecaya untuk dapat membantu menanggulangi bencana COVID-19.

Relawan SIBAT merupakan relawan aktif PMI untuk menangani kebencanaan. Baginya, Masyarakat merupakan aset terbesar sebagai relawan yang berada di garis depan dalam pelayanan kemanusiaan pada saat bencana terjadi di lingkungan masing-masing. PMI menggagas sebuah program bernama SIBAT untuk mengurangi risiko bencana yang dialami oleh masyarakat. Fokus utama SIBAT adalah bergerak Bergerak Bersama Masyarakat dan mengutamakan keberpihakan kepada masyarakat yang memerlukan bantuan. Begitupun dengan masyarakat yang tidak bisa bergerak secara mandiri dalam menghadapi kasus COVID-19.

Keterlibatan relawan SIBAT yang dilakukan oleh PMI Kota Bekasi dalam menanggulangi COVID-19 dapat mendorong percepatan kegiatan kebencanaan dengan partisipasi masyarakat yang ada di lingkungan wilayahnya. Partisipasi ini dibangun untuk membentuk modal sosial yang dapat mengatasi sebuah permasalahan kebencanaan. Hal ini diperkuat dari penelitian (Paidi, 2012) yang menyatakan bahwa, penanggulangan bencana dapat dikatakan berhasil apabila melibatkan sektor lain yang juga dapat berfungsi sebagai aktor kebencanaan antara lain seperti, organisasi yang dibentuk kelompok anggota masyarakat secara sukarela yang dikenal sebagai LSM (Lembaga Swadaya Masyarakat) atau organisasi non kepemerintahan atau NGO (NonGovernment Organization) yang melibatkan pemerintah dalam skenario kebencanaan. Pola sinergitas dalam penanggulangan bencana berbasis masyarakat membutuhkan modal sosial yang saling terintegrasikan dengan unsur penting yang ada di dalamnya meliputi, bonding, bridging, dan linking sehingga dalam penanganan bencana saling memperkuat satu dengan lainnya: 1) Bonding meliputi hubungan yang harmonis antara komunitas. PMI Kota Bekasi menjalin dan menjaga hubungan yang harmonis kepada masyarakat yang menjadi pendukung utama dalam melakukan tugasnya. Hubungan yang baik dan harmonis ini ditandai dengan kepercayaan masyarakat terhadap program SIBAT yang digagas oleh PMI Kota Bekasi. Kepercayaan masyarakat muncul karena eksistensi PMI yang sudah menjadi organisasi kemasyarakatan dan kemanusiaan selama 76 tahun. PMI melakukan berbagai aksi dalam penanggulangan bencana dimulai dari pemberian pelatihan sampai dengan penyuplai alat-alat fasilitas penanggulangan COVID-19 di wilayah tempat tinggal masyarakat. Sebagai organisasi dibidang kepalangmerahan dan kemanusiaan PMI tidak diragukan lagi mengenai kinerja, mengingat PMI selalu dilibatkan dalam kegiatan kebencanaan yang ada di Indonesia. Pelibatan ini dituangkan kedalam UU No 1 Tahun 2018 tentang kepalangmerahan dan mandat yang diberikan kepada PMI berdasarkan Keputusan Presiden No.25 tahun 1950 dan No.246 Tahun 1963, dimana PMI sebagai organisasi dipercaya membantu pemerintah dalam kepalangmerahan dan kegiatan kemanusiaan. Kepercayaan inilah yang menjadi kapital terbesar bagi PMI dalam membentuk sebuah modalitas sosial.

Modalitas sosial yang terbentuk memunculkan suatu kepercayaan dalam organisasi, sehingga akan memudahkan pencapaian suatu tujuan bersama yang diinginkan (Dollu, 2020). Seperti halnya masyarakat Kota Bekasi yang percaya dengan kinerja atau peran dari PMI Kota Bekasi maka akan memudahkan kerjasama yang terjalin dalam memerangi COVID-19 di Indonesia khususnya di Kota Bekasi. Selain itu, adanya feedback seperti, meminta saran dan dialog jajak pendapat terkait penanggulangan COVID-19 yang diberikan oleh masyarakat melalui SIBAT menandakan 
bahwa hubungan yang dilakukan oleh PMI Kota Bekasi dengan masyarakat diterima secara baik.

2) Bridging, meliputi keuntungan yang dihasilkan dari suatu hubungan. Kerja sama yang dilakukan PMI Kota Bekasi dalam menjalankan kegiatan penanggulangan bencana COVID-19 berbasis masyarakat tidak terlepas dari adanya opinion leader sebagai penyampaian pesan dalam kebencanaan. Hasil penelitian di lapangan menunjukkan bahwa PMI Kota Bekasi dalam menanggulangi bencana COVID-19 berbasis masyarakat menggunakan peran opinion leader tokoh masyarakat untuk menggerakan masyarakat di wilayah masing-masing. Salah satu tokoh masyarakat yang dilibatkan antara lain adalah RT dan RW yang memiliki pengaruh di dalam lingkungannya untuk menggerakan masyarakat dan relawan SIBAT.

Peran tokoh masyarakat ini digunakan untuk mempercepat proses keberhasilan dalam kegiatan kebencanan sebagai pemuka pendapat (Lestari, 2018). Diperkuat oleh penelitian dari (Rosyida, Ainun, Ratih Nurmasari, 2019) yang menyatakan bahwa adanya keterlibatan tokoh masyarakat sebagai pemuka pendapat (opinion leader) memberikan pengaruh yang dapat memengaruhi sikap dan perilaku seseorang didalam suatu kegiatan penanggulangan bencana. Penelitian selanjutnya dari (Susanto, 2011) yang menyatakan bahwa tokoh masyarakat memiliki kedudukan kepercayaan dalam masyarakat di kawasan rawan bencana.

Keterlibatan tersebut membentuk sebuah kerja sama antara PMI Kota Bekasi dengan masyarakat setempat untuk menanggulangi bencana COVID-19. Hubungan ini merupakan hubungan yang saling menguntungkan atau mutualisme. PMI Kota Bekasi diuntungkan oleh masyarakat karena kinerja PMI Kota Bekasi menjadi lebih mudah dan ringan karena adanya bantuan dari masyarakat. Jumlah program SIBAT yang masuk di wilayah di Kota Bekasi mencapai 10 kelurahan dan 6 kecamatan dari jumlah keseluruhan 56 kelurahan dan 12 kecamatan.
Hal ini membuktikan bahwa SIBAT sudah dapat diterima di Kota Bekasi sebagai pendukung utama dalam menangani COVID-19. Selain itu, tokoh masyarakat berhasil memengaruhi masyarakat di wilayahnya untuk bergabung di dalam program yang dibentuk oleh Palang Merah Indonesia.

Selain itu, PMI Kota Bekasi juga mengetahui apa saja yang sedang dibutuhkan oleh masyarakat karena informasi didapatkan dari masyarakat secara langsung. Sebaliknya masyarakat merasa diuntungkan dengan adanya PMI Kota Bekasi dalam penanggulangan COVID-19 ini karena masyarakat mendapatkan ilmu pengetahuan yang belum didapatkan sebelumnya sehingga dapat diterapkan dan dipraktikkan di lingkungan wilayahnya dalam menanggulangi COVID-19. Selain itu, masyarakat juga mendapatkan alat dan fasilitas pendukung untuk penanggulangan COVID-19 seperti alat cuci tangan, penyemprotan disinfektan, masker dan lainnya. 3) Linking, meliputi makna yang tercipta dari adanya hubungan yang dijalin antara anggota masyarakat dengan kelompoknya. Hubungan yang dijalin antara masyarakat dengan PMI Kota Bekasi dalam menanggulangi COVID-19 di Kota Bekasi memiliki makna tersendiri sebagai unsur penting dalam Teori Modal Sosial.

"Gotong Royong" merupakan makna yang tercipta antara hubungan PMI Kota Bekasi dengan masyarakat melalui programnya yakni SIBAT dalam menanggulangi COVID-19 di Indonesia. Makna gotong royong memiliki arti sebagai kerja sama antara satu dengan yang lainnya secara baik yang dilakukan untuk saling bantu membantu dalam menyelesaikan suatu permasalahan ataupun pekerjaan tertentu (Widayati, 2020:1). Gotong Royong mampu melawan COVID-19 karena tercipta kerja sama untuk memutus penyebaran COVID-19 dan bukan menitikberatkan kepada pemerintah saja namun juga sektor. Hal ini menjadi momentum untuk bersatu dalam melawan virus corona dan dapat melewatinya dengan baik (Jamaludin et al, 2020:41). 
Kesamaan penelitian terlihat dari penelitian (K \& Umam, 2019) dengan peneliti yang ditunjukkan oleh peneliti terdahulu yang menyatakan bahwa komunikasi bencana tidak dapat terlepas dari dukungan aktor kebencanaan lainnya berupa stakeholder. Tentunya selaras dengan hasil penelitian peneliti menunjukkan bahwasannya PMI Kota Bekasi tidak dapat berjalan dengan sendiri dalam melakukan komunikasi bencana. PMI Kota Bekasi membutuhkan aktor kebencanaan lainnya berupa stakeholder (pemangku kepentingan) seperti, warga masyarakat, tokoh masyarakat seperti RT, RW. Perbedaan penelitian ini yang dilakukan peneliti dengan penelitian terdahulu yang dilakukan oleh (K \& Umam, 2019) yakni pengkajian yang dilakukannya. Peneliti terdahulu mengkaji secara umum dengan menggunakan metode studi literatur untuk menjelaskan konseptual dari penelitian yang diteliti, sedangkan penelitian yang dilakukan dalam penelitian ini melihat pengaplikasian konsep Komunikasi Bencana Haddow \& Haddow dengan Teori Modal Sosial pada fenomena yang ada di lapangan. Kesamaan penelitian berikutnya dari penelitian (Noor et al., 2020) dengan peneliti yang ditunjukkan oleh peneliti terdahulu bahwa komunikasi bencana ini dapat digunakan sebagai respon dan pemulihan akibat risiko bencana yang terjadi. Karena terdapat produksi pesan mengenai informasi kebencanaan dan juga ajakan-ajakan mitigasi bencana. Tentunya selaras dengan hasil penelitian yang dilakukan peneliti. Kesamaan penelitian juga terlihat dari penelitian (Murliana et al., 2020) dengan peneliti yang ditunjukkan oleh peneliti terdahulu menyatakan bahwa komunikasi bencana mengalami penerimaan dengan baik oleh masyarakat sekitar sebagai objek penelitian. Dalam penelitian terdahulu ditemukan persamaan dan perbedaan antara lain adalah penelitian (Murliana et al., 2020) lebih mengarah dan condong kepada unsur kebudayaan dengan menggunakan media tradisional wayang sebagai penyampaian informasi kebencanaan.
Wayang digunakan karena wilayah kabupaten Purworejo merupakan sebagian besar bersuku Jawa yang terkenal mampu menjaga kebiasaan adat istiadat dan kebudayaannya sehingga masyarakat tersebut menerima karena adanya persepsi pemahaman mengenai keyakinan yang dianut, nilai, dan sikap. Sedangkan komunikasi bencana yang dilakukan oleh PMI Kota Bekasi melalui pendekatan SIBAT ini lebih bersifat general karena masyarakatnya bersifat heterogenitas plural, bermacam-macam suku dan keyakinan yang ada (Pemerintah Kota Bekasi, 2017). Media yang digunakan sebagai penyampaian pesan kebencanaan beragam mulai dari tradisional yakni mulut ke mulut melalui sosialisasi, edukasi, pelatihan, poster dan juga menggunakan media modern seperti media sosial. Penerimaan komunikasi bencana PMI Kota Bekasi dalam menanggulangi COVID-19 melalui SIBAT dapat diterima dengan baik karena adanya kebutuhan dari masyarakat.

\section{Simpulan}

Siaga Bencana Berbasis Masyarakat (SIBAT) yang dimiliki oleh PMI Kota Bekasi merupakan modal sosial yang dibangun sebagai sinergitas antara masyarakat dengan PMI Kota Bekasi untuk menanggulangi COVID-19 demi memutus mata rantai penyebaran. Dalam modal sosial yang terbentuk, peran komunikasi bencana sangat penting sebagai mitigasi bencana dengan memberikan sumbangsih dan keuntungan bagi masyarakat di Kota Bekasi untuk melakukan pencegahan dan penanganan COVID-19. Landasan utama komunikasi bencana yang digunakan untuk penyampaian informasi berupa data kebencanaan (Situational Awareness) seperti wilayah yang terpapar COVID-19, melihat kebutuhan masyarakat (constumer service) mengenai penyemprotan disinfektan, cara isolasi mandiri yang baik, cara cuci tangan yang baik, pembangunan fasilitas pencegahan COVID-19 dan pendistribusian seperti masker, sabun cuci tangan, dan 
handsanitizer yang merupakan PHBS (Perilaku Hidup bersih Dan Sehat) sebagai kebijakan yang dikeluarkan (Leadership commitment), serta aksi nyata (soft power dan hard power).

Penelitian ini memberikan kontribusi berupa rekomendasi kepada semua sektor yang ada di Indonesia bahwa penanganan COVID-19 menjadi tanggungjawab bersama tidak hanya pemerintah maupun tenaga medis. Penanggulangan COVID-19 tidak dapat dijalankan secara sendiri dibutuhkan sinergitas antar sektor sebagai modal sosial sebagai faktor penting demi mencapai tujuan bersama.

\section{Ucapan Terima Kasih}

Ucapan terima kasih peneliti sampaikan kepada para informan, Dr. Edy Prihantoro, M.I.Kom., MMSI, selaku pembimbing dalam penulisan penelitian ini, dan Rizky Wulan Ramadhani, S.I.Kom., M.I.Kom, selaku rekan penulis yang membantu dalam penelitian ini.

\section{Daftar Pustaka}

Abidin, S. (2021). Komunikasi Bencana Dalam Mencegah Dan Mengurangi Kepanikan Masyarakat Di Masa Pandemi Covid-19. Al-Muaddib : Jurnal Ilmu-Ilmu Sosial Dan Keislaman, 6(1), 15-22. http://jurnal.umtapsel.ac.id/index.php/al-muaddib/article/ view/3062

Antara. (2021). Ridwan Kamil Sebut 6 Daerah Masuk Zona Merah: Termasuk Kabupaten dan Kota Bekasi. Metro.Tempo.Co. https:// metro.tempo.co/read/1426683/ridwankamil-sebut-6-daerah-masuk-zona-merahtermasuk-kabupaten-dan-kota-bekasi/ full\&view $=$ ok, [Diakses pada 10 Februari 2021]

Arnani, M. (2020). Epidemiolog: Kasus Corona di Indonesia Masih Akan Terus Naik, Ini Alasannya. Kompas. Com. https://www.kompas.com/tren/ $\mathrm{read} / 2020 / 11 / 30 / 155542165 /$ epidemiologkasus-corona-di-indonesia-masih-akanterus-naik-ini-alasannya?page $=$ all, [Diakses pada 5 Februari 2021]
Wijaya, A, M., M, A., Sadat, A., Azhar Sa, L., Suherman, A., Fajar Maulana, H., \& Rizal Ardiansah Putra, M. (2019). Pemanfaatan Modal Sosial Dalam Penguatan Program Desa Tangguh Bencana. Jurnal Pengabdian Kepada Masyarakat Membangun Negeri, 2(1), 1-13.

Badan Pusat Statistik Kota Bekasi. (2020). Jumlah Penduduk Kota Bekasi (Jiwa), 2018-2020. Bekasikota.Bps.Go.Id. https:// bekasikota.bps.go.id/indicator/12/29/1/ jumlah-penduduk-kota-bekasi.html, [Diakses pada 29 April 2021]

Burhanuddin, A. I, Massi, M, N., Marsuki., Tharir, H., Razak, A., T. S . (2020). Merajut Asa Di Tengah Pandemi Covid-19 (Pandangan Akademisi UNHAS). Deep Publish (Grup Penerbit CV Budi Utama).

Dollu, E. B. S. (2020). MODAL SOSIAL: Studi tentang Kumpo Kampo sebagai Strategi Melestarikan Kohesivitas Pada Masyarakat Larantuka di Kabupaten Flores Timur. Warta Governare: Jurnal Ilmu Pemerintahan, Vol 1 No 1(Januari-Juni), 59-72.

Effendi Sianturi, Maida Pardosi, E. S. (2019). Kesehatan Masyarakat. Zifatama Jawara.

Ertiana Dwi, Maria Ulfa, Aspiyani, Silaturrokhmah, N. W. Y. P. (2020). Darmabakti Jurnal Pengabdian dan Pemberdayaan Masyarakat Peningkatan Peran Serta Masyarakat Dalam Maduretno Kecamatan Papar Kabupaten Kediri. 02(November), 23-33.

Fitra, S. (2021). Perkembangan Terkini Covid-19 di Indonesia: Total Kasus Capai 2.228.938 Kasus (Jumat, 2/7). Databoks.Katadata. Co.Id. https://databoks.katadata.co.id/ datapublish/2021/07/02/perkembanganterkini-covid-19-di-indonesia-total-kasuscapai-2228938-kasus-jumat-27\#, [Diakses pada 16 April 2021]

Gilmore, B., Ndejjo, R., Tchetchia, A., De Claro, V., Mago, E., Diallo, A. A., Lopes, C., \& Bhattacharyya, S. (2020). Community 
engagement for COVID-19 prevention and control: A rapid evidence synthesis. BMJ Global Health, 5(10). https://doi. org/10.1136/bmjgh-2020-003188

Helmi, M. (2020). Ontologi Penelitian Hukum Islam Berbasis Paradigma Guba dan Lincoln. Jurnal Hukum Islam, 18(1), 1-20.

Hermanto Suaib, B. S. (2017). Nilai-Nilai Kearifan Lokal dan Modal Sosial dalam Pemberdayaan Masyarakat Suku Moi. An1mage Studio.

Hidayat, D., Gustini, L. K., \& Dias, M. P. (2020). Digital Media Relations Pendekatan Public Relations dalam Menyosialisasikan Social Distancing di Kota Bandung. Jurnal Ilmu Komunikasi, 18(3), 257. https://doi. org/10.31315/jik.v18i3.3575

Ismail Nurdin, S. H. (2019). Metodologi Penelitian Sosial. Media Sahabat Cendekia.

Jamaludin, A. Nururrochman Hidayatulloh, I Ketut Sudarsana, Marulam MT Simarmata, Irwan Kurniawan Soetijono, Robert Tua Siregar, Marto Silalahi, Oris Krianto Sulaiman, Syifa Saputra, Masrul Masrul, Akbar Yuli Setianto, Ramen A Purba, Karwanto Karwanto, If, N. H. (2020). Belajar dari Covid-19: Perspektif Sosiologi, Budaya, Hukum, Kebijakan dan Pendidikan. Yayasan Kita Menulis.

K, F. A., \& Umam, C. (2019). Komunikasi Bencana Sebagai Sebuah Sistem Penanganan Bencana Di Indonesia. Mediakom : Jurnal Ilmu Komunikasi, 3(1), 25-37. https://doi. org/10.35760/mkm.2019.v3i1.1980

Kadji, Y. (2016). Metode Penelitian Ilmu Administrasi. Deep Publish.

Kanwar, V. T. \& P. (2012). Understanding Social Media. In Journal of Chemical Information and Modeling (Vol. 53, Issue 9).

Katriana. (2020). JK sebut PMI terus hadir di garda terdepan setiap bencana. Antaranews. Com. https://www.antaranews.com/ berita/1731578/jk-sebut-pmi-terus-hadir-digarda-terdepan-setiap-bencana\#mobile-src, [Diakses pada 9 Maret 2021]
Kholil, Setyawan, A., Ariani, N., \& Ramli, S. (2019). Komunikasi Bencana Di Era 4.0 : Review Mitigasi Bencana Gempa Bumi Di Lombok Propinsi Nusa Tenggara Barat (Disaster Commuication In 4.0 Era : Review Earthquake Disaster Mitigation In Lombok West Nusa Tenggara). Prosiding Seminar Nasional Penelitian \& Pengabdian Pada Masyarakat, 212-215.

Kriyantono, R. (2016). Teknik Praktis Riset Komunikasi. Prenada Media Group.

Lestari, P. (2018). Komunikasi Bencana: Aspek Penting Pengurangan Risiko Bencana. In Journal of Chemical Information and Modeling (Vol. 53, Issue 9). PT Kanisius (Anggota IKAPI).

Lestari, P. (2019). Manajemen Komunikasi Bencana Melalui Komunikasi Massa. In Perspektif Komunikasi Bencana.

Lestari, P., Ritonga, R., Ruliana, P., \& Barus, C. C. B. (2020). Disaster communication uses field training exercise simulation as an important aspect of disaster risk reduction. Jurnal Komunikasi: Malaysian Journal of Communication, 36(1), 166-186. https://doi. org/10.17576/JKMJC-2020-3601-10

Lestari, P., Sembiring, I. D. P. B., Prabowo, A., Wibawa, A., \& Hendariningrum, R. (2012). Manajemen Komunikasi Bencana Saat Tanggap Darurat. Jurnal Ilmu Komunikasi, 10(2), 139-158. http://repository.upnyk. ac.id/5043/

Lidwina, A. (2020). Kasus Aktif Covid-19 Kota Bekasi Paling Banyak di Jawa Barat. Databoks.Katadata.Co.Id. https://databoks. katadata.co.id/datapublish/2020/07/28/ kasus-aktif-covid-19-kota-bekasi-palingbanyak-di-jawa-barat, [Diakses pada 10 Juli 2021]

Maher, R., \& Murphet, B. (2020). Community engagement in Australia's COVID-19 communications response: learning lessons from the humanitarian sector. Media International Australia, 177(1), 113-118. https://doi.org/10.1177/1329878X20948289 
Murliana, Nurul, F., \& Mia, M. (2020). Komunikasi Dalam Penanggulangan Bencana Oleh Badan Nasional Penaggulangan Bencana (BNPB) Melalui Pendekatan Budaya. Daring Mahasiswa Komunikasi, 1(1), 37-45.

Noor, F., Ayuningtyas, F., \& Prihatiningsih, W. (2020). Disaster Communications for Handling Coronavirus Disease 2019 ( COVID-19 ) in Indonesia. International Journal of Multicultural and Multireligious Understanding, 2019, 25-35.

Norzistya, A. D., \& Handayani, W. (2020). Modal sosial dalam ketahanan komunitas terhadap bencana banjir di Kelurahan Kemijen dan Krobokan, Kota Semarang. Region : Jurnal Pembangunan Wilayah Dan Perencanaan Partisipatif, 15(2), 206. https:// doi.org/10.20961/region.v15i2.29694

Nugroho, S. P., \& Sulistyorini, D. (2018). Komunikasi bencana: membedah relasi bnpb dengan media. In Pusat Data, Informasi dan Hubungan Masyarakat, Badan Nasional Penanggulangan Bencana.

OCHA. (2020). Rencana Operasi Multisektor Penanganan Covid-19 Indonesia. In indonesia.un.org. Kantor PBB untuk Koordinasi Urusan Kemanusiaan (OCHA) dan Kantor Koordinator Lembaga Perserikatan Bangsa-Bangsa (RCO) di Indonesia, bekerja sama dengan mitra kemanusiaan dan pembangunan di Indonesia. OCHA dan RCO. https://indonesia.un.org/ en/93075-indonesia-multisectoral-responseplan-covid-19, [Diakses pada 3 Maret 2021]

Paidi. (2012). Pengelolaan manajemen risiko bencana alam di indonesia. Widya, 83, 37.

Pemerintah Kota Bekasi. (2017). Wali Kota Bekasi Buka Festival Generasi Unggul, Tri Sukses Generasi Penerus. Bekasikota.Go.Id. https:/www.bekasikota.go.id/detail/walikota-bekasi-buka-festival-generasi-unggultri-sukses-generasi-penerus

PMI. (2021). VISI DAN MISI. Pmi.or.Id. from https://pmi.or.id/, [Diakses pada 16 Februari 2021]
PMI \& IFRC. (2020). Rapid Assessment Persepsi Komunitas Terhadap COVID-19. PMI Pusat. https://communityengagementhub.org/wpcontent/uploads/sites/2/2020/05/200429IFRC-Rapid-Assessment-CommunityPerception-on-COVID-19-IND.pdf, [Diakses pada 24 Juni 2021]

PMI Pusat. (2007). Kesiapsiagaan Bencana Berbasis Masyarakat. Markas PMI Pusat

Rohmah, N. N. (2020). Media Sosial Sebagai Media Alternatif Manfaat dan Pemuas Kebutuhan Informasi Masa Pandemik Global Covid 19 (Kajian Analisis Teori Uses And Gratification). Al-I'lam: Jurnal Komunikasi Dan Penyiaran Islam, 4(1), 1-16. https:// journal.ummat.ac.id/index.php/jail/article/ view/2957/1905

Rosyida, Ainun, Ratih Nurmasari, \& S. (2019). Analisis Perbandingan Dampak Kejadian Bencana Hidrometeorologi Dan Geologi Di Indonesia Dilihat Dari Jumlah Korban Dan Kerusakan (Studi: Data Kejadian Bencana Indonesia 2018). Jurnal Dialog Penanggulangan Bencana, 10(1), 12-21.

Samatan, N. (2017). Riset Komunikasi 1. Gunadarma.

Saputri, C. D., Lestari, P., \& Sosiawan, E. A. (2021). Audit Komunikasi Media Sosial di Masa Krisis COVID-19. Jurnal Ilmu Komunikasi, 19(1), 19. https://doi. org/10.31315/jik.v19i1.4720

Schiavo, R. (2020). Advocacy, community engagement and cross-sectoral collaborations as key strategies during COVID-19 response and beyond: New directions for a new decade. Journal of Communication in Healthcare, 13(1), 1-5. https://doi.org/10.1 080/17538068.2020.1762983

Soeparno, K., Rahmawati, I., Kurniawan, Y., Chizanah, L., Khiroh, R. K., Fachrunisa, R. A., Kusujiarti, S., Rahardjo, A. P., Pramumijoyo, S., Nilasari, H., Sunjono, Joko., B. S. D. (2020). Ragam Ulas Kebencanaan. Deep Publish (Grup Penerbit CV Budi Utama). 
Spialek, M. L., \& Houston, J. B. (2019). The influence of citizen disaster communication on perceptions of neighborhood belonging and community resilience. Journal of Applied Communication Research, 47(1), 1-23. https://doi.org/10.1080/00909882.20 18.1544718

Sukmono, F. G., Wijayanti, Y. T., Bajari, A., Gemiharto, I., Wahyudin, U., Karimah, K. El, Widhagdha, M. F., Pertiwi, C. A., Prihantoro, E., Yusriah, K., Putranto, A., Wijiharto, P., Rasyid, E., Rahmawati, W., Kurniawati, D., Ardiyansah, R., Junaedi, F., Istiyanto, S. B., Sjafirah, N. A., ... Devi, P. (2019). Komunikasi Lingkungan dan Komunikasi Bencana di Indonesia (Y. T. W. Filosa Gita Sukmono (ed.)). Buku Litera Yogyakarta.

Surjaya, A. M. (2021). Kota Bekasi Sudah Terbebas Zona Merah COVID-19. Metro.Sindonews.Com. https://metro. sindonews.com $/ \mathrm{read} / 354082 / 171 /$ kotabekasi-sudah-terbebas-zona-merahcovid-19-1614845010, [Diakses pada 9 Maret 2021]

Susanto, E. H. (2011). Eksistensi komunikasi dalam menghadapi bencana. Karya Ilmiah Dosen, March 2011, 1-14.

Suwendra, I. W. (2018). Metodologi Penelitian Kualitatif dalam Ilmu Sosial, Pendidikan, Kebudayaan Dan Keagamaan. Nilacakra.

Syafruddin, Suprianto, B. D. (2020). Modal Sosial Dan Kesejahteraan Petani Perdesaan. Literasi Nusantara.

Tanzil, Jamaluddin Hos, \& Muhammad Arsyad. (2019). Modal Sosial dan Mitigasi Bencana pada Masyarakat di Pulau Makasar Kota Baubau. Talenta Conference Series: Local Wisdom, Social, and Arts (LWSA), 2(1), 1-7. https://doi.org/10.32734/lwsa.v2i1.638
Wahyu, F., Flora, D., Yulinda, D., Yuliani, T., Iswadi, I., Irwandi, I., Budiman, N., Hanafi, B. P., \& Rikarno, R. (2020). Peran Masyarakat Dalam Menekan Laju Pemberantasan Covid-19 Di Kabupaten Tanah Datar. Alfuad: Jurnal Sosial Keagamaan, 4(2), 40. https://doi.org/10.31958/jsk.v4i2.2354

Waluyo, D. (2021). Kasus Covid-19 di Kota Bekasi Melonjak, Paling Tinggi di Kecamatan Bekasi Utara. Megapolitan. Kompas.Com. https://megapolitan.kompas. $\mathrm{com} / \mathrm{read} / 2021 / 06 / 29 / 15301781 / \mathrm{kasus}-$ covid-19-di-kota-bekasi-melonjak-palingtinggi-di-kecamatan-bekasi? page $=$ all, [Diakses pada 11 Juli 2021]

Wan. (2021). Covid Di Bekasi Meningkat, Wawalkot Bekasi Tinjau Penanganan Covid Di Wilayah. Bekasikota.Go.Id. https:// www.bekasikota.go.id/detail/covid-dibekasi-meningkat-wawalkot-bekasi-tinjaupenanganan-covid-di-wilayah, [Diakses pada 11 Juli 2021]

Warsono, A. (2021). Kasus Covid-19 di Bekasi Melonjak 90 Persen, Wali Kota: Rumah Sakit Umum Penuh. Metro.Tempo.Co. https://metro.tempo.co/read/1474334/kasuscovid-19-di-bekasi-melonjak-90-persenwali-kota-rumah-sakit-umum-penuh/ full\&view $=$ ok, [Diakses pada 12 Juli 2021]

Wekke, I. S. (2021). Mitigasi Bencana. Adab.

Widayati, S. (2020). Gotong Royong (M. Nur Rokhim (ed.)). Alprin.

Widnyana, I. M. A, Farhaeni, M., Sudarsana, I. K., Wirta, I. W., Januariawan, I. G., Binawati, N. W. S., Citranu., Santika, I. G. N. (2020). COVID-19: Perspektif Hukum dan Sosial Kemasyarakatan. Yayasan Kita Menulis.

Wijaya, H. (2018). Analisis Data Kualitatif Ilmu Pendidikan Teologi. Sekolah Tinggi Theologia Jaffray. 